\title{
Social Adjustment of College Students in Relation to Gender
}

\author{
Shruti A. Suthar ${ }^{1}$

\section{ABSTRACT:} \\ The present investigation is to find out the difference in the social adjustment of college students \\ with regard to their gender. The total random sample consisted 100 (50 Male and 50 Female) \\ college students belonged from various colleges of Mehsana city. 'Social Adjustment Inventory' \\ developed by R. C. Deva (1990) was administered as a tool for the study. The obtained data were \\ analyzed by using ' $t$ '-Test. The result shows that there is no significant mean difference in Social \\ Maturity and Social Adjustment of male and female college students. There is significant mean \\ difference in Emotional Adjustment of the college students in relation to their gender.
}

Keywords: Social Adjustment

The problem of adjustment being faced by our adolescents, needs serious consideration. It has been rightly estimated that $18^{\text {th }}$ century was characterized by enlightenment, the $19^{\text {th }}$ century by progress and development where as the $20^{\text {th }}$ century is characterized by anxiety and conflict. The mechanical and busy life has exposed affecting their adjustive capacity. The term 'adjustment' used several times without clarifying its exact meaning. The concept of adjustment was originally borrowed from biology. It was modeled after the biological term 'adaptation', which refers to effect by a species to adjust to change in its environment. Thus adjustment refers to the psychological processes through which people manage or cope with the demands and challenges of everyday life.

\section{SOCIAL ADJUSTMENT :}

"Social Adjustment may take place by adapting the self to the environment or by changing the environment." - Campbell,Psychiatric Dictionary (1996).

As far as previous study are concerned The National Center For Educational Statistic found that approximately one third of entering college students leave higher education without obtaining degree, and most do so during their 1st year (Bradburn \& Carroll,2002) Previous studies have suggested that relationships and making meaningful connections are important for students to adjust to the college environment (Rice, Fitz Gerald, Whaley \& Gibbs,1995).

\footnotetext{
${ }^{1}$ M.A, GSET) Ph. D Student, Hemchandracharya North Gujarat Uni, Patan(N.G)
} 
Social Adjustment may be just as important as academic adjustment according to Gender. Mallinckrodt (1994) who studied 155 freshmen and found that "Personal Adjustment and integration into the social fabric of campus life play a role at least as important as academic factors in students relation." Numerous studies conducted in the 1990s indicated that students needs continued support to become involved in activities and that this improves their overall adjustment (Dinger, 1999).

\section{Problem of the study}

The problem of the present study is as under :

"Social Adjustment of college students in relation to gender."

\section{OBJECTIVE}

The objective of present study is as under :

(1) The purpose of present study is to measure Social Maturity of male and female college students.

(2) The purpose of present study is to measure Emotional Adjustment of male and female college students

(3) The purpose of present study is to measure Social Adjustment of male and female college students

\section{HYPOTHESIS}

(1) There is no significant mean difference between male and female college students in Social Maturity.

(1) There is no significant mean difference between male and female college students in Emotional Adjustment.

(2) There is no significant mean difference between male and female college students in Social Adjustment.

\section{Variables of the study :}

Following variables were selected for the present study :

\section{(1) Independent Variable :}

Male and Female college students who belong to various colleges of Mehsana city. 


\section{(2) Dependent Variable :}

Score of Social Adjustment Scale.

\section{METHOD :}

Survey method was chosen for data collection, Social Adjustment Inventory developed by R.C.Deva(1990) was administered to college students who belong to various colleges of Mehsana city.

\section{(1) Selection of the sample :}

The total random sample of present study consisted 100 college students (50 Male and 50 Female) from different colleges of Mehsana city situated in North Gujarat.

\section{(2) Tool :}

"Social Adjustment Inventory" developed by R.C.Deva(1990) was used to differences between male and female college student's Social Adjustment. Total 100 statements were given to answer. High score is to be interpreted as good Social Adjustment and low score as poor Social Adjustment.

\section{(3) Procedure :}

After establishing rapport with college students "Social Adjustment Inventory" was administered. All the instructions were strictly followed which were given in the manual of inventory.

\section{(4) Data Analysis :}

SPSS for windows was used for descriptive statistics as under :

(1) Mean

(2) Standard Deviation (SD)

(3)'t'- Value.

\section{RESULT \& DISCUSSION}

The obtained results are shown in the following tables.

Table No. 1 - Social Maturity of Male and Female college students.

\begin{tabular}{|l|l|l|l|l|l|l|l|}
\hline No. & Group & N & Mean & SD & df & 't'-Value & Level of Significant \\
\hline 1 & Male & $\mathbf{5 0}$ & $\mathbf{9 1 . 0 1}$ & $\mathbf{3 3 . 6}$ & $\mathbf{9 8}$ & $\mathbf{0 . 2 1}$ & NS* \\
\hline 2 & Female & $\mathbf{5 0}$ & $\mathbf{9 2 . 0 6}$ & $\mathbf{3 8 . 1 1}$ & & & NS* \\
\hline \multicolumn{8}{|c|}{0.01 and 0.05 level. }
\end{tabular}


As above mentioned Table No. 1 shows that there is no significant mean difference between male and female college students in Social Maturity. The result is no significant so null hypothesis is accepted. The mean difference shows that there is little difference between Male(91.01) and Female(92.06) college students.

Table No. 2 - Emotional Adjustment of Male and Female college students.

\begin{tabular}{|l|l|l|l|l|l|l|l|}
\hline No. & Group & N & Mean & SD & df & 't'- Value & Level of Significant \\
\hline 1 & Male & $\mathbf{5 0}$ & $\mathbf{3 4 . 8 5}$ & $\mathbf{1 4 . 3 6}$ & $\mathbf{9 8}$ & $\mathbf{5 . 6}$ & Sig* \\
\hline 2 & Female & $\mathbf{5 0}$ & $\mathbf{4 9 . 2 4}$ & $\mathbf{2 4 . 4 6}$ & & & Sig* \\
\hline \multicolumn{7}{|l}{ *Significant at 0.01 and 0.05 level. } \\
\end{tabular}

As above mentioned Table No. 2 shows that there is significant mean difference between male and female college students in Emotional Adjustment. The result is significant so null hypothesis is not accepted.

Table No. 3 - Social Adjustment of Male and Female college students.

\begin{tabular}{|l|l|l|l|l|l|l|l|}
\hline No. & Group & $\mathbf{N}$ & Mean & SD & df & 't'- Value & Level of Significant \\
\hline $\mathbf{1}$ & Male & $\mathbf{5 0}$ & $\mathbf{4 2 . 2 1}$ & $\mathbf{2 0 . 3 8}$ & $\mathbf{9 8}$ & $\mathbf{0 . 3 1}$ & NS* \\
\hline $\mathbf{2}$ & Female & $\mathbf{5 0}$ & $\mathbf{4 3 . 5 6}$ & $\mathbf{1 6 . 5 5}$ & & & NS $^{*}$ \\
\hline \multicolumn{7}{|c|}{ *Insignificant at 0.01 and 0.05 level. }
\end{tabular}

As above mentioned Table No.-3 shows that there is no significant mean difference between male and female college students in Social Adjustment. The result is no significant so null hypothesis is accepted. The mean difference shows that there is little difference between Male (42.21) and Female (43.56) college students.

\section{CONCLUSION}

We can draw conclusion this present study as under :

(1) There is no significant mean difference between male and female college students in Social Maturity.

(2) There is no significant mean difference between male and female college students in Emotional Adjustment.

(3) There is no significant mean difference between male and female college students in Social Adjustment.

\section{SUGGESTION}

(1) This study is limited for only 100 college students, I suggest that large sample should be taken for further study. 
(1) This study is confined to the only for college students.

(2) This study is only limited for Mehsana city, I suggest that the variable of rural and urban should be taken for the further study.

\section{REFERENCES}

1. Bradburn, E.M., \& Carroll, C.D.(2002,November). Short-term enrollment in postsecondary education : Student background and institutional differences in reasons for early departure, 1996- 1998 Pittman \& Richmound 359. Report No. NCES 2003, Washington.

2. Campbell, Psychiatric Dictionary (1996) : www.reference.md/../mD012917

3. Dinger, M.K.(1999). Physical activities and dietary intake among college students, American Journal of Health Studies. P.No.139-148

4. Mallinckrodt(1994).Loneliness,learned resourcefulness, and self-esteem in college students, Journal of counseling and Development, P. No. 460-469.

5. Rice, K.G., Fitz Gerald, D.P.,Whalen, T.J., \& Gibbs, C.L.,(1995). Cross-sectional and longitudinal examination of attachment, separation-individualism, and college social adjustment, Journal of Counseling and Development, P. No.463-469.

6. Weiten Wayne and Lloyd Margaret (2004), Psychological applied to modern lifeadjustment in the 21st century (P. No.-11), Thomson Wadsworth, Singapore. 